\title{
THE TABAROID DIALECTS OF THE CENTRAL ALBORZ: LANGUAGE CONVERGENCE BETWEEN TABARI AND PERSIAN
}

\author{
HABIB BORJIAN \\ Encyclopaedia Iranica, Columbia University, New York \\ 450 Riverside Drive, New York City 10027, USA \\ e-mail: hb146@columbia.edu
}

\begin{abstract}
Persian surrounds much of the Tabari (or Māzandarāni) speaking area, that is, the province of Māzandarān south of the Caspian Sea. The transition zones between the two languages lay in the valleys and foothills of the Alborz range, which separates Māzandarān from the Iranian Plateau. Within this zone we find a range of hybrid dialects that are divided into two distinct groups: Persian dialects influenced by Tabari and vise versa. This study aims at the latter group, which we call Tabaroid, i.e., Tabari varieties carrying various amounts of Persian mix. The linguistic data come from some twenty villages in the south-central Alborz, separated from Tehran by a mountain ridge. The main objective here is to establish the dialectal and areal position of the Tabaroid varieties by closely examining their diachrony, phonology, and above all morphosyntax.
\end{abstract}

Key words: Iranian languages, Caspian dialects, Māzandarāni, Jājrud, diachronics, typology, areal distribution, language convergence.

Along the Caspian littoral and the northern slopes of the Alborz mountain range, the Caspian language family forms a continuum of dialects that extend some 500 kilometres along the latitude. This chain of dialects, called gelaki by their six to seven million speakers, can be broken down areally into three language groups: Gilaki in the west, Tabari in the east, and, in the middle, the transitional Central Caspian, embracing the districts of Tonekābon and Kalārdasht in Māzandarān province. Tabari (or Māzandarāni) predominates throughout the province of Māzandarān, in and around the nuclei cities of Sāri, Shāhi, Bābol, and Āmol, whose speech forms Tabari proper. Most Tabari speakers, however, dwell in a series of close-knit villages spread across the Caspian lowlands as well as in the mountain valleys of the Alborz range. Dialectal continuum varies in two geographical directions: east-west (valley variation) and north-south (lowland vs. highland). Almost every settlement has its own subdialect, and even neighbouring villages may exhibit substantial phonological difference. Lexicon, however, is fairly uniform throughout the province. 
The transitional zone between Tabari and its surrounding Persian has long been a murky area in Iranian dialectology. A recent study by this author (Borjian 2013a) has shed light on the language relationships in the south-central Alborz, located between Māzandarān and Tehran. A thorough analysis based on 48 isoglosses from 35 localities spread out throughout the region revealed two distinct contiguous linguistic spaces. (1) The dialects spoken in the lower Jājrud, Shemirān, and Damāvand are characteristically Persian with a rich Tabari imprint in the verb phrase. (2) Those spoken in the upper reaches of the Jäjrud and Karaj river valleys show a solid Tabari character in phonology, lexis, and verb morphology, but a strong Persian blend in the noun phrase. Accordingly, these dialects were designated as "Tabaroid". The numerical results of that study are summarised in Table 1 . The percentage points indicate the affinity of each of the fifteen dialects to Tabari proper. The lexical, morphological, and phonological categories are listed in individual columns and their average is shown in the right column. As seen in the table, Velātru'i distinguishes itself by showing full agreement in all categories with Tabari proper; hence, it is not "Tabaroid" but a Tabari variety in spite of its geographical location.

Table 1. Tabari isogloss agreements (percent) ${ }^{1}$

\begin{tabular}{|c|c|c|c|c|c|}
\hline \multirow{2}{*}{$\begin{array}{l}\text { Location } \\
\text { (valley) }\end{array}$} & \multirow{2}{*}{ Village } & \multicolumn{3}{|c|}{ Isogloss Categories } & \multirow{2}{*}{ Average } \\
\hline & & Lexical & Morphological & Phonological & \\
\hline Velātru & Velātru & 100 & 100 & 100 & 100 \\
\hline \multirow{7}{*}{ 疍 } & Darbandsar & 71 & 90 & 93 & 85 \\
\hline & Shenestān & 79 & 89 & 86 & 84 \\
\hline & Lālun & 71 & 80 & 93 & 82 \\
\hline & Meygun & 64 & 80 & 87 & 77 \\
\hline & Garmābdar & 71 & 80 & 67 & 73 \\
\hline & Jirud & 71 & 60 & 73 & 68 \\
\hline & Amāma & 50 & 89 & 47 & 62 \\
\hline \multirow{5}{*}{ 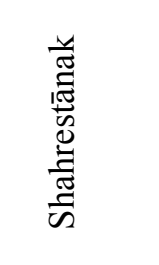 } & Lāniz & 57 & 89 & 73 & 73 \\
\hline & Shahrestānak & 64 & 75 & 80 & 73 \\
\hline & Shelnag & 43 & 89 & 73 & 68 \\
\hline & Hamajā & 50 & 56 & 80 & 62 \\
\hline & Āsārā & 29 & 56 & 60 & 48 \\
\hline \multirow{2}{*}{ Irā } & Irāa & 79 & 80 & 67 & 75 \\
\hline & Veskāra & 71 & 75 & 67 & 71 \\
\hline
\end{tabular}

${ }^{1}$ Source: Borjian (2013a). 


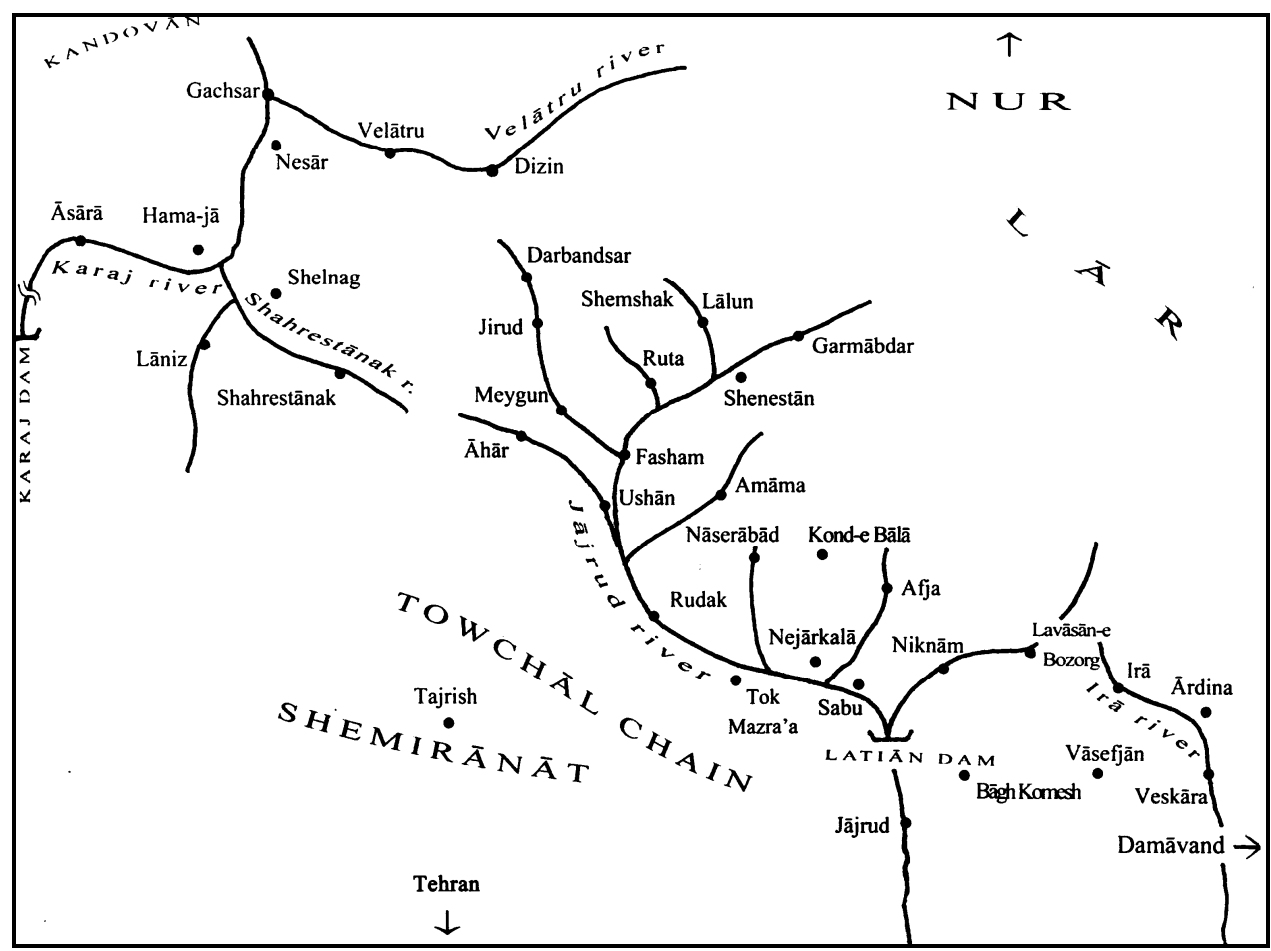

Map 1. The Jājrud and Karaj river valleys, north of Tehran (Courtesy of the author)

The present paper follows up the above-mentioned study. Once we have classified a group of dialects as "Tabaroid" based on a selected number of isoglosses, we then need to define them on grammatical terms, as in exactly which morphological and syntactic categories they diverge from Tabari proper in favour of Persian. In this paper, I have added three more settlements for which linguistic data became available. The following is a list of villages included, roughly arranged corresponding with their latitude from north to south. These valleys are often collectively referred to as Qasrān (see Map 1).

(1) The Velātru valley: Velātru, ${ }^{2}$ Dizin

(2) The upper tributaries of the Jājrud river: Lālun, Ābnik, Garmābdar, Shenestān, Shemshak, Darbandsar, Jirud, Meygun, Amāma

(3) The Shahrestānak valley: Shahrestānak, Shelnag, Lāniz, Hamajā

(4) The Irā valley: Irā, Veskāra

The linguistic materials for the dialects are rather fragmentary. The examples from the Jājrud and Karaj river valleys are selected from the volume compiled by

${ }^{2}$ Velātru'i examples are kept to a minimum; it is studied in details in Borjian (2012a). 
Giti Deyhim (2005), who lists several random sentences of everyday speech for each of the dozens of dialects spoken in the region. I have included all relevant data that are both sound and verifiable in terms of their provenance. The data on the dialect of Dizin is from a short text (Kalbāsi 2009, pp. 353-354). Velātru'i materials are from Lambton (1938).

\section{Diachronics}

The Caspian provenance of the dialects within the Northwest (NW) branch of Iranian languages is evident in the following characteristic sound changes, which also illustrate intense Perside (SW) intrusions.

D1. From the oldest Iranian stratum, the words that exhibit the NW-SW differentiation are just a few: zumâ 'son-in-law' (NW z $<$ proto-Iranian *ź $<$ proto-Indo-European ǵ); esbi (Irā esvi) 'white' (NW sp < proto-Iranian *św < proto-Indo-European *ḱkw); esyo/assiyu/issiov 'water-mill' (SW s $<$ Old Iranian * $\theta \mathrm{r}$ ).

Most dialects have gosand 'sheep' (cf. Pers gōspand < Old Iranian *gavspandārmad- 'holy cattle'); it is possible that the word carries the SW form sandārmad (cf. Armenian Sandaramet) with the development proto-Iranian *św > SW s.

D2. Within the Middle West Iranian split, the NW association is far from solid:

Old Iranian *-č- (from proto-Indo-European * $\mathrm{k}^{(\mathrm{w})}$ ) > NW j: paj- 'cook', jir 'under', jur 'above', tij 'shrp', and probably kija 'girl' and saja 'broom', but SW ruz 'day'.

Retention of Old Iranian *j (from proto-Indo-European $* \mathrm{~g}^{(\mathrm{h})}$ ) has no example; we rather find SW zanâ 'woman' (<*jani- + fem. *-ā?), zan- : zu- 'hit'.

OId Iranian * $\mathrm{dw}>\mathrm{SW} \mathrm{d}$ : (a) di 'again, also'.

Old Iranian *y- > SW j: ju, jöu 'barly', jâ 'place' (cf. Pth. wyāg, Mid. Pers gyāg).

Within the New Iranian stage, major non-Persian characteristics are:

D3. Retention of Middle West Iranian *w-, as in valg 'leaf', vara/vare 'lamb', vârun, vâreš 'rain', varf 'snow', veni/vini 'nose', verg 'wolf', vešna 'hungry' (but many counterexamples are found in various dialects).

D4. Reduction of consonantal clusters, typical of NW Iranian dialects, is predominant:

*-xr- > r/l: tal 'bitter'

*-fr- is not reduced but is metathesised in varf 'snow' ( $<*$ Old Iranian *wafra-)

$* \mathrm{fr}->\mathrm{r}$ in res- 'send', rut- 'sell' (< Old Iranian *fra-waxta-); $>\mathrm{h}$ in the preverb $h \hat{a}$ /he- $(<*$ frā-, $*$ fra- $)$

*xt > t: pat- 'cook', rut- 'sell', Shp detar 'daughter' (but Dar, Mey raxd 'clothing', Lnz saxdi 'difficulty' belong to a different stock) 
*ft > t: kat- 'fall', Āhā miratan 'they would go' (but mefd 'free of charge', etc.). This example suggests a late development because the stem raft- is obviously a loanword from Persian.

D5. The plosives are voiced in consonantal clusters, a characteristic of all Qasrān dialects:

št > šd: Mey, Amā dašd 'plain', Āhā pošd 'back', Hmj gušd 'meat', Mey, Shr dâšd'have'

st > sd: Jir ̌̌asd 'sixty', Hmj pusd 'skin', Mey basd- 'tie', Lln rusdâ'i 'villager'

st > ss: Lln, Dar ass- 'be', Dar muness- 'remain', Lln xâss- 'want', peressâ 'he stood up' (but all dialects bist 'twenty')

sp > sb: Lnz, Mey, Lln, Amā, Shr, Hmj, Lnz, Shl esbi, Jir esbid (but Irā esvi) 'white' (but in most dialects gosand 'sheep'; see also D1)

šk > šg: Mey xošg 'dry', ešgen 'brake', Lnz, Dar mošgel 'difficult'

Note also: kt > gd in Shn degder 'doctor', bt > pt in Dar eptedâyi 'primary (school)'.

D6. *hw/xw- is reduced to $\mathrm{x}$, e.g. xâxər 'sister', xo/xu/xöu 'sleep', and the reflexive $x o-$. However, we find the stems (past : present) fes- : fet- 'sleep' in all Tabaroid dialects of Qasrān. It is comparable with Velātru'i $f_{\varepsilon s-}$ : $f_{\varepsilon} t$-, Kandelusi, fes- : fet-, Yushi fes- : xet- (but most other Tabari dialects xəs- : xət-); Karingāni fes- : het-, New Pers xufs-/xusp- : xuft- 'sleep'; Kandelusi da-fiss- 'soak' (see Borjian 2012a, D6).

D7. Original postvocalic stops $*_{\mathrm{t}} *_{\mathrm{p}} *_{\mathrm{k}}(>\mathrm{Mid}$. West Iranian $\mathrm{d} \mathrm{b}$ g) are lost. (1) Medial and final dental: barâr 'brother', mâr 'mother', pi(a)r 'father', râhxona 'river' mâ 'female', šu- 'go', xo- 'self'. (2) Old labials are absorbed into the preceding vowel, which is rounded as a result (*ằ $>\mathrm{u}): u / o ̈ u$ 'water' (also in esyo/assiyu/issiov 'watermill'), xо/хu/xöu 'sleep', šu/šo/šöu 'night' (<*xšap-), ofdöu 'sun'), to/tu/töu 'bend', tu 'fever', kuk 'partridge', kahu 'blue', to(v)esdun 'summer' (<*tap-), gu/go/göu 'cow' (< Old Iranian *gă̄v-). (3) Medial palatal is lost in deru 'lie', šâl 'jackal', $\operatorname{dia}(r) /$ deya 'other'.

D8. Āhā xâzenda 'solicitation in marriage' has parallels in various Tabari dialects: xâzendi 'id.', xâzekâr 'solicitor'; Old Tabari $x^{w} \bar{a} z$ - 'want', $k \bar{e} n-x^{w} \bar{a} z$ 'one who seeks revenge' (Borjian 2009, p. 100); Old Gorgāni $x^{w} \bar{a} z-/ x^{w} \bar{a} s ̌ t-$ 'want' (Borjian 2008).

\section{Phonology}

1.1. The consonants show little variation from those of Persian. The vowel inventory has the additional umlauted $\ddot{u}$ and $\ddot{o}$ with sporadic occurrence; these are allophonic however. The existence of a lax central vowel, typical of the Caspian languages, can be inferred from inconsistent documentations, especially of the terminal vowel; for instance, Shr emuna/e 'they would come' is likely to be emunə. 
The following phonological processes are observed in the verb phrase.

1.2. The third singular person ending II (see Table 4, below) drops optionally after the stems ending in a vowel: Shl biâmu' 'he came', Lln bimu ${ }^{-a}$ 'it came', but ba-di-a 'it

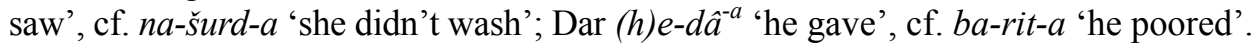

1.3. The terminal $e / a$ in personal endings is coalesced with the clitic conjunctive $o / u$ : Shr serx âkerdenu ( $\leftarrow$ âkerdene $\_$) 'they would fry [it] and...'.

1.4. When the stem ends in a vowel, the initial $i$ of the ending changes to $y$ : Grm bi-e$y n$ [bijejn] 'come ye!' ne-ye-yn [nejejn] (neg.) (cf. na-kon-in 'do not!').

1.5. The epenthesis $e$ is inserted after consonants, but not after $r$ or $y:{ }^{3}$ Dar ey-nena 'they come', Mey šur-nena 'they wash', Lnz, Grm dâr-mi 'we have', Grm âr-ma 'I bring', xor-na 'it eats', kâr-mi 'we sow'.

1.6. When the stem ends in $n$, a dissimilation process occurs to distinguish between the plural and singular endings: Grm, Mey, Lnz kondena $(\leftarrow$ kon- + -nena) 'they do', Grm kondeni 'you do'. But note Lnz da-ven-nan 'they bake' (from the stem venn- or vend- 'tie, coagulate').

1.7. Initial $g$ is lost in some stems when preceded by a verbal prefix: Mey $b a-y r$-im 'that we sieze', Lln ba-yt-ena 'they seized', Lln h-it-emi 'we picked up', Shl ha-yt-a 'he would buy' (cf. Mey gitema 'I would take'); Grm $b-u-i$ 'that you say' (cf. Grm goni 'you say', gone 'he says').

1.8. Initial consonant of the stem sometimes duplicates when preceded by a verbal prefix: Mey ba-kkoten-im 'that we pound', Grm na-ttu-mi 'we cannot'.

1.9. Hiatus-bridge $-r$ - appears between the verbal prefix and the stem in certain verbs: Lln pe-r-essâ 'he stood up', Grm pe-r-es-na 'they stand up', hâ-r-š-am 'that I see'.

\section{Noun Morphology and Syntax}

2.1. Number. Parallel to the Persian -(h) $\hat{a}$, plurals in -un sporadically appear for both the animate and inanimate: Dar mehmunun 'guests', Lnz kuhun 'mountains', Amā bozun-i šâx 'goats' horn', boz-i šâxun 'goat horns'. The forms for 'men' and 'women' show inter-dialectal divide among the dialects with two distinct plural markers -un and -âkun: (i) Lnz, Amā, Āhā mardun 'men', zanun 'women'; (ii) the northernmost dialects: Dar, Jir, Mey, Lln, Shn, Shl, Hmj, Āsā mardâkun/mardâkon/mardakun 'men',

\footnotetext{
${ }^{3}$ This rule possibly extends, as it does in some Tabari varieties, to the stems ending in $l$, no example of which was found in the limited available data. 
zanâkun/zanâkon/zenâkun 'women'. Note concoction in Grm, Shr mardun 'men', zanakun/zanâkun 'women').

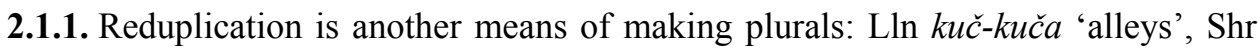
mard-mard 'men', kuč-kučak 'small pieces', yâl-yâl, 'children'. Note also Dar yemyâlak, Shr yemyâl 'children' (cf. Lnz yemyâl 'family').

2.2. Modifiers. While the Tabari adjectival and genitival construction is the norm, many speakers have adopted the Persian ezā $f{ }^{5} .^{5}$ In the Tabari forms the oblique marker $-e$ is suffixed to the head noun in possessives, adjectives, and objects of postpositions. Examples:

Dar dir-e jâ 'far place', Hasan-i mâr 'Hasan's mother', yemyâlak-i raxd 'children's clothes', kadxedâ-yi ârus 'the headman's daughter-in-law', piar-t-i harf-e gušs âkon 'listen to your father's words'

Mey in râhxona-i sang-a vese bairim 'we had to take this river stone'

Amā tamum-e in bozun-i šâx-e veyne čarb konin 'you must grease all these goats' horn', boz-i šâxun-a hama-re alu badin 'burn all the goat horns'

Shl sâb arussi-i xune-i dam 'by the house of the master of the wedding'

Shr dim-š-e merqüne-i zardi demâlniâna 'they spread egg yolk on it', tutak-a yâlyâl-i das dâna 'they would hand the tutak to the children', bozorgtarun- $i$ didan 'to visit elders'

2.3. Pronouns. Two parallel constructions occur: (1) the three main classes of Caspian personal pronoun (subject, object, possessive) are attested in most dialects; (2) Persian-type enclitic pronouns are used with equal frequency.

2.3.1. Personal pronouns are basically Tabari, with the following infected forms:

1st sg.: Mey, Shl men 'I', Dar mane 'me', meni 'my', Irā, Vsk meše 'mine'

2nd sg.: Āsā, Shr, Irā, Vsk te, Dar teni 'your', Irā, Vsk teše 'yours'

3rd sg.: Dar, Mey vi 'he', Grm vire 'him', Vsk une 'his'

1st pl.: Dar emâ, Lln, Lnz, Grm, Shn amâ, Mey âmâ, Hmj mâa 'we', Dar, Lnz ameni 'our', Grm amener 'for us'

2nd pl.: Grm šemi 'your'

3rd pl.: Lnz unâhâ 'they', Dar vešuni, Irā vene 'their'

\footnotetext{
${ }^{4}$ In Kalārdashti the plural ending -âkón is apparently limited to zenâkon 'women' and merdâkon (pl. of mardi) 'men'; otherwise the plural markers are -ón for the animate nouns (mardomon 'people') and, more frequently, -(e)šón (rikāǎson 'boys', a jozešon 'walnuts').

${ }^{5}$ Examples: Lln taraf-e Hâšemâbâd 'toward H.', amâ tefl-e rusdâ'i assemi 'we are rural children'; Shn boz-e kuhi 'wild goat'; Dar parvande-ye emâ 'our file', Hmj čarm-e pusd-eš-o migitan 'they would get the leather of its skin'.
} 
Examples: Dar meni mošgelât 'my problems', Shl meni arussi 'my wedding', Lnz ameni zenâ 'our wife (i.e. my wife)', Grm šemi kuča-i sar 'at your alley', Dar kenišena 'whose is it?'

2.3.2. Enclitics are similar to those in Persian, except the occasional pronunciation of the fricatives as affricates in the third person singular and plural, leading to the set: $-m,-t,-\check{s} /-\check{c},-m u n,-t u n,-\check{s} u n /-\check{c} u n{ }^{6}$ Examples:

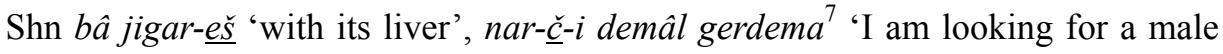
[goat]'

Jir sấl-čc-a (Pers sâl-aš-râ) 'his age', ektešâfât-č-e (Pers ektešâfât-aš-râ) 'his discoveries'

Lln az tars-emân 'out of our fear'

Grm barâ-ye ruz-e mabâdâ-mun 'for the day of our destitution (for the sake of precaution)'

Dar piar-t-i harf 'your father's words'

Shr dim- $\underline{-}-e$ 'of his face'

Shl pesar- $\underline{-}-e r$ 'for his son'

Lnz berâr-m-i pali dara 'he is with my brother, ${ }^{8}$ komak-ěs konim 'that we help her', Lnz baresami-š 'we sent him to...', dela-šsun 'in them', yemyâl-čcun-e baverdena Karaj 'they took their family to Karaj', yek-i detâ-šun xoččun inje zendegi kondena, zan o yâl-čun unja 'a couple of them are living here by themselves, and their wives and children there'

Hmj čarm-e pusd-eš-o migitan 'they would get the leather of its skin'

2.4. Reflexives. Tabari invariable pronoun $\check{s} e$ 'self' is absent in Qasrān. Instead, the reflexive is built on the stem xo-, suffixed by the enclitics: Grm xommun 'ourselves', Lnz xoččun $(\leftarrow$ xod-šun ) 'themselves'.

2.5. Deixis. The dialects generally have in 'this', un 'that', but Irā im 'this', Shn inâhan 'these'. The form ine/une is employed as the subject: ${ }^{9}$ Lnz ine mošgel_a 'this is difficult'; Shl ine arussi nave 'this was not a [proper] wedding', une ge biamu 'the one who came'.

2.6. Adpositions. The region exhibits a mixed nature in adpositions: the use of postpositions, an outstanding characteristic of Caspian, drops as one travels south along the Jājrud valley or west in the Shahrestānak valley. Ablative is expressed by the Persian preposition $a z-$, rather than Tabari postposition $-j a /-j a ̂$ in all dialects. Table 2 shows the adpositions that occur in our material.

\footnotetext{
${ }^{6}$ Dizini, spoken in Velātru valley, has no enclitic pronouns, and therefore like Velātru'i leans toward Tabari proper more than the dialects of Jājrud valley.

${ }^{7}$ Possibly equivalent to Pers donbâl-e nar-aš migardam.

${ }^{8}$ Notice the Persian enclitic pronoun co-occurring with Tabari postposition!

${ }^{9}$ Cf. ina in Shemirāni; see Borjian $(2012 b, 2.3 .3)$.
} 
Table 2. Adpositions

\begin{tabular}{|c|c|c|}
\hline Dialect & Postpositions & Prepositions \\
\hline Lln & dela in, dim on & $a z$ from \\
\hline Grm & $e r$ for, sar at/on & $a z$ from, barâ-ye \\
\hline $\bar{A} b n$ & dela in & $a z$ from \\
\hline Shn & demâl following & $b \hat{a}$ with \\
\hline Amā & dela in, sar at/on & \\
\hline Mey & $\begin{array}{l}\text { dele, sar at/on, ben under, } \\
\text { dim on, lenge by }\end{array}$ & $a z$ from, $b \hat{a}$ with, $t u$ in \\
\hline Shr & dela in, pali near & \\
\hline $\operatorname{Lnz}$ & dele in, pali near & $b e$ to, $b \hat{a}$ with \\
\hline Shl & $e r$ for, dam at & \\
\hline Dar & $e r$ for & $a z$ from, $b \hat{a}$ with \\
\hline Hmj & & $a z$ from \\
\hline Jir & & $a z$ from, $b e$ to \\
\hline $\bar{A} h \bar{a}$ & & $a z$ from, pošd-e behind \\
\hline Irā & & $a z$ from, $b e$ to, $b \hat{a}$ with \\
\hline
\end{tabular}

Examples of postpositions: Grm šemi kuča-i sar 'at the head of your lane', Mey in raxd-i sar bakkotenim 'we pound [it] on the clothes', Diz hamme-ye mostun_am zamini-i sar bašenessa 'all of the yogurts spilled on the ground', Shl sâb-arussi-i xune-i dam 'by the house of the master of the wedding', Lln jir kata jub-i u-i dela 'it fell down into the water of the ditch', dočarxa-ra bazume âber-i dim 'I ran the bicycle onto the pedestrian's face', Mey korsin-i lenge hâkešim 'that we spread [it] by the korsi'.

2.6.1. The postposition -er 'for' is characteristic to the area:

Diz zano men-er vača urna 'the wife will bring me children'

Dar mehmunun-er nâhâr pajna 'she will cook for the guests'

Shl burin hime-y-er ${ }^{10}$ felun jâ 'for firewood go to such and such place'

Shl Maš Asqar veyne pesar-č-er arussi bakone 'M. A. wants to arrange wedding for his son'

Shl bâbâ-m vese men-er arussi bakone 'my father wanted to arrange wedding for me' Grm amener če be-dard xorna? 'what is its use for us?'

Grm čečer 'for what' (cf. Pers čiči-râ, či-râ, čerâ)

Dar dir-e še:r (?) našu! 'don't go too far away!'

${ }^{10}-y$ - is epenthesis. Cf. accusative hima-re. 
This postposition is found in no other Iranian language known to this author. However, there are comparable postpositions in the dialects surrounding Māzandarān: Tabari dialect of Parvar (probably Shahmirzadi, north of Semnān) me-r vačče 'my child', vačče-r gune 'she tells the child' (Kalbāsi 2009, p. 180); Shahmirzādi me-vra 'for me' (idem, p. 532); Gorgāni Persian of Taqiābād: man-ere bas bud 'it was enough for me' (idem, p. 224). Otherwise, 'for' is expressed in most Tabari dialects by -ves(s)e/-es(s)e. Some Tabari varieties have an alternate form ending in $r$ (Sāravi -vesser, Elāshti -vâser), comparable to the postposition -er that we saw above for the Tabaroid dialects of Qasrān. Note also Kandelusi -re 'for'; Kalārdashti (v)âseré 'for', mâr-e âsere 'for the mother'; Tonekāboni mérara, térarə, vérarə, ámar(a)ra, šémerara, ušânerra 'for me, etc.'.

\section{Verb Morphology and Syntax}

3.1. Stems. A regular past stem is formed by suffixing $-i$ to the present stem, e.g. Lln xer- : xeri- 'eat'. This marker is employed in all causative present stems, formed systematically by adding -(e)n- to the intransitive present stem: Mey koten- 'pound', Shr mâln- 'rub'.

Tabari has some verbs that employ more than a binary set of stems typical of West Iranian languages, and the Tabaroid dialects of this study exhibit this feature at least for the verb 'go', which is conjugated based on four stems: $\check{s} u-, ~ s ̌ i-, ~ b u r-$, burd-. Table 3 below compares the occurrence of this verb in the dialects of Rudbār-e Qasrān against those of Espivard district in central-eastern Māzandarān, whose examples are listed in the second person singular.

Table 3. Conjugation of 'go'

\begin{tabular}{|c|c|c|c|}
\hline & & Espivard & Qasrān \\
\hline \multirow{2}{*}{ Imperative } & aff. & bur! & Shl bur-in 'go ye!' \\
\hline & neg. & nášu! & Dar $n a-\check{s} u$ 'go not!' \\
\hline \multirow[t]{2}{*}{ Subjunctive } & aff. & $b u ́ r-i$ & $\begin{array}{l}\text { Lln bur-am, Lnz bur-im, Shr bur-an } \\
\text { 'that I, we, they go' }\end{array}$ \\
\hline & neg. & $n a ́-s ̌ s-i$ & \\
\hline Present & aff. & $\check{s} \dot{u}-n i$ & $\begin{array}{l}\text { Grm } \check{s} u-m a, \check{s} u-n i, \check{s} u \text {-nena' 'I, you, they } \\
\text { go' }\end{array}$ \\
\hline \multirow{2}{*}{ Preterit } & aff. & búrd-i & Lln burd-ema, Shn burd-emi 'I, we went' \\
\hline & neg. & $n a ́-s ̌ i l-i$ & \\
\hline Imperfect & aff. & $\check{s} i-i$ & $\begin{array}{l}\text { Lln ši-mi, Šmš šina, Irā ši-ne, } \\
\text { Shr šine/šiena 'we, they would go' }\end{array}$ \\
\hline
\end{tabular}


3.2. Preverbs are as frequent as they are in Tabari:

ha/(h)â: Dar (h)e-dâ 'he gave', Lln $h$-it-emi 'we picked up', Shl ha-yt-a 'he would buy', Mey hâ-keši-m 'that we spread on', gaht â-kord-ema 'I reared', Jir hâkord-emi 'we did', Ābn kuj âkenan 'that they migrate'

da-: Irā da-ken-an 'that they put into', Shr šir da-kord-ene 'they poured the milk in', de-mâlniâna 'they would spread', Lnz da-ven-nan 'they bake'

dar-: Shl dar-engu-na 'they would toss [coins into a container]', Shr šekl-e âdem der-geyrd-ene 'they would shape [the bread] in human form', Lln dar-ši-mi 'we would run away'

3.2.1. Preverbs have two functions. (1) Lexically, they may expand or specify the stem, as in Lln šimi 'we would go' $\neq$ dar-šimi 'we would run away' '11; Jir hâ-kordemi 'we did' $\neq$ Shr da-kordene 'they poured into'. (2) Morphologically, preverbs replace the non-durative modal prefix $b a-/ b e-(3.3 .1)$. These two functions may contradict in the imperfect, which is distinguished from the preterit only by deletion of the modal prefix. Subsequently, two strategies are employed: (a) When the preverb is semantically irrelevant, it drops in the imperfect; for instance, for the verb 'have', which shares stem with no other verb, we have Mey ø-dâ-ma 'I would give' (cf. Dar he-dâ 'he gave'). (b) When meaning is at stake, the preverb stays on the verb at the expense of a merge between the imperfect and preterit: Shl ha-yt-a 'he would buy' (which also means 'he bought'), Shl dar-engu-na 'they would toss'. For stability of the preverbs in compound verbs, see 3.3.1.2.

\subsection{Prefixes}

3.3.1. The modal prefix $b a$-/be- (or a preverb) marks the subjunctive (e.g. Mey $b$ ešgen-im 'that we brake'), the imperative (Shl bi-ör-in 'bring ye!'), and the preterit (Lln ba-di-ne 'they saw'). Duration is inferred when the modal prefix is lacking: (present indicative) Dar paj-na 'she cooks'; (imperfect) Mey basd-ema 'I would tie'. The modal prefix is the only means to distinguish between the preterit and the imperfect: Dar $d i-a$ 'he used to see' $\neq$ Lln $b a-d i-a$ 'he saw'. See also 3.2.1.

3.3.1.1. The verbs 'have' and 'want' take no modal prefix in the preterit: Mey dâšdema 'I had', Lln xâsse-ma 'I wanted'. These forms can also be understood as imperfects.

3.3.1.2. In compound verbs, the modal prefix/preverb may remain or drop: Ābn $k u j$ âkenan 'that they migrate', Mey gaht â-kord-ema 'I reared'; Dar guš â-kon 'listen!' Shr serx $\hat{a}$-kerdenu 'they would fry and...', diden ø-kordena 'they would visit', $k u c ̌$ kučak xâr ø-kordene 'they would make it in little pieces'; Lln banâ kerd-a 'he began

\footnotetext{
${ }^{11}$ Used as preterit in the text, an obvious mistake.
} 
to', vel kerd-ena 'they let go'; Shl jam korda 'he gathered' (cf. the imperfect xabar kordene 'they would inform').

3.3.2. The negative marker $n a$ - precludes the modal prefix $b a$-, e.g. Dar na-muness- $a$ 'it didn't remain', ne-hešt-a 'it didn't allow'; as a result, the distinction between the preterit and imperfect disappears (see 3.6.2 for examples).

3.4. Personal Endings. The common pattern appears to be three sets of personal ending, as shown in Table 4. Set I is used for the indicative present, II for the preterit and the imperfect and for the present of the substantive verbs, and III for the subjunctive present.

Table 4. Personal Endings

\begin{tabular}{rlll}
\hline & I & II & III \\
\hline Sg. 1 & $-(e) m a$ & $-(e) m a$ & $-a m$ \\
2 & $-n i$ & $-i$ & $-i$ \\
3 & $-n e$ & $-e /-a$ & $-e$ \\
P1. 1 & $-(e) m i$ & $-(e) m i$ & $-i m$ \\
2 & $-(e) n e n i$ & $-(e) n i$ & $-i n$ \\
3 & $-(e) n e n a$ & $-(e) n a$ & $-a n$ \\
\hline
\end{tabular}

3.5. Tenses. The materials at hand yield five simple and two periphrastic structures, as shown below. As in Tabari proper, the present perfect merges with the preterit.

\begin{tabular}{|c|c|c|c|c|c|c|}
\hline Pres. indic. & $=$ & & & pres. stem & + & ending I \\
\hline Pres. subj. & $=$ & prev./be- & + & pres. stem & + & ending III \\
\hline Imperative & $=$ & prev./be- & + & pres. stem & + & zero (sg.), -in (pl.) \\
\hline Preterit & $=$ & prev./be- & + & past stem & + & ending II \\
\hline Imperfect & $=$ & & & past stem & + & ending II \\
\hline Pluperfect & $=$ & prev./be- & + & past part. & + & past copula \\
\hline Past subj. & $=$ & prev./be- & + & past part. & + & subj. copula \\
\hline
\end{tabular}

3.6. Be and Become. The following stems/preverbs occur:

$\begin{array}{llll} & \text { be } & \text { be in } & \text { become } \\ \text { present } & \text { (ass)- } & \text { dar- } & \text { bu, vu- } \\ \text { subjunctive } & \text { bavu- } & \text { davu- } & \text { avu-? } \\ \text { past } & \text { be(y)- } & \text { da(y)-, dav- } & \text { bay-, bav- }\end{array}$


3.6.1. There are two verbs 'be': the substantive and the locative (with the preverb $d a(r)$-). Both verbs employ Set II endings for all tenses; the third singular ending has different forms. These verbs function as the auxiliary in the periphrastic and progressive tenses (see 3.7). Examples:

\section{Substantive}

Pres. Dar Hasan rikâ-ye xub-i_alassa 'Hasan is a good boy', Lln ass-emi 'we are', Lnz bâ-ham_ena 'they are together'

Subj. Lnz ba-vu (Pers bâšad) 'that it be', na-vuan (Pers nabâšand) 'that they are not ${ }^{12}$

Past Jir bey-ma 'I was', Lln, Dar bey-mi, Shn be-mi 'we were', Šmš, Shn bey-na 'they were', Lln, Jir be 'it was', Shn bâmarefat $b e$ 'he was descent', Shr bo 'it was', Mey gâhre bey- $a$ 'there was the cradle'

\section{Locative}

Lnz dar-e 'is in', dar-ena 'they are in, Ābn dar setam darena 'they are in hardship'

Mey âfdâb da-vu (Pers dar âftâb bâšad) 'that it be in the sun'

Dar day-mi 'we were in', Shn dav-e 'there was in', Mey dav-e tâ šu 'he was there till night', $t \hat{a}$ fardâi sob... dav-eya 'he was there until morning'

The following forms remain unrecognised: Dar age vârun bie (Pers bâšad) 'if there is rain', Šmš xeyli saxd beya 'it was very difficult', Shn bebo 'it was/they were?' beboa 'it was/became?' The last two forms are compatible with the subjunctive bavu-but do not occur in the subjunctive mood in the texts.

3.6.2. The copula and locative verbs appear to merge in the negative: Lln nay-ma 'I wasn't', Irā na-ve 'was not', Shl ine arussi na-ve 'this was no wedding', Shr mive $n a-v e$ 'there was no fruit', Mey boxâri na-ve 'there was no heater'.

3.6.3. 'Become' employs the base $b u$ - : $b a v$-, the preverb $\hat{a}$ - (sometimes), and regular ending. Examples are limited to:

Present Dar xub bu-na 'it gets well', Grm nârâhât bu-na 'he gets annoyed', na-vu-neni 'you don't become'

Subj. Mey xošg $\hat{a}-v u(-e)$ 'that it get dry'

Past Lln suâr bay-mi 'we got on', rahâ bay-mi 'we lost control', Shn sir bav-emi 'we got satisfied', Shl jam bey-na 'they would gather', pul kam jam be 'little amount of money used to be saved'

\subsection{Perfective and Progressive Tenses}

3.7.1. The pluperfect forms by the past participle (see 3.9) of the main verb succeeded by the past tense of 'be' (3.6): Dar âkord be 'he had done'.

\footnotetext{
${ }^{12}$ See also 3.7.2.
} 
3.7.2. The past subjunctive occurs in the following examples:

Shl bâs men burd bâm un pul-e hâdâ bâm 'I needed to go and pay that money'

Shl har qâter-i jelu biâm ${ }^{u}$ bâ 'whichever mule took the lead'

Grm zamin-e xodâ hâda bâa 'God has given this earth'; also zamin xodâ dâda bâa 'id.'.

In Tabari proper, the subjunctive past is made by the past participle plus the subjunctive of the verb 'be'. If the examples above actually belong to this same category, the subjunctive base of 'be' should be $b \hat{a}$ - in Shelnag and Garmābdari. This stem is not found in Tabari proper (cf. Lnz bavu-, in 3.6.1), but it does exist in Central Caspian: Rāmsari šâyad bogut(a) bâm 'I may have said'; Tonekāboni agar vere dai-beyti bi, itâ návone bâ 'if you had paid attention to her, this wouldn't have happened'. More linguistic data from the Tabaroid dialects is therefore needed to clarify this point.

3.7.3. In Progressive tenses, the locative verb (3.6.1) is employed as auxiliary, either fully conjugated or invariably in the third person singular form for all persons. Examples: (present) Lnz dare inja zendegi komi 'we are living here'; (past) Dar dave xordema 'I was eating', Diz davema getema 'I was saying'.

3.8. Modals. The impersonal veyne/vese 'must' is succeeded by the imperative, subjunctive, or infinitive of the main verb: Amā veyne čarb konin 'you must grease [it]'; Lnz amâ veyne burim 'we must go'; Grm veyna četi âkerdan? 'what must one do?' or 'what should be done?'; Mey yax-e vese bešgenim 'we should break the ice'; Shl un qâter-a vese kalle âden 'they out to give the mule a sugar cone'.

3.8.1. veyne/vese is also used in the sense of 'want': Lnz veyne nun davennan 'they want to bake bread'; Shl veyne pesar-č-er arussi bakone 'he wants to set up wedding for his son'; bâbâ-m vese mener arussi bakone, ... '[when] my father wanted to arrange a wedding for me, ...'; un-moqe arussi vese bakonan 'when they wanted to marry...'.

3.8.2. Another impersonal form, bâs ( $<$ bâyest; also current in colloquial Tehrani) is used in: Shl bâs men burd-bâm 'I needed to go'.

\subsection{Verbal Nouns}

3.9.1. The past participle employed in the periphrastic forms is formed with the past stem and a modal prefix: $\hat{a}-k o r d$, burd, ha-dâ, bi-âm ${ }^{u}$ (see 3.7.1-2). The same structure holds when the past participle is used as an adjective: Shr anâr yaxdun-čun- $i$ dela qâm-kord dâšdena, yâ si qâm-bokord dâšdena 'in their icebox they had pomegranates hidden, or they held apples out of sight'. 
3.9.2. The infinitive is formed by the past stem, the suffix -an, with or without a verbal prefix: Lln kerdan, Grm âkerdan 'to do', Shr diden kordena 'they would visit'.

\begin{tabular}{llll} 
& \multicolumn{3}{c}{ Abbreviations } \\
Ābn & Ābniki & Lln & Lāluni \\
$\overline{\text { Āhā }}$ & Āhāri & Lnz & Lānizi \\
Amā & Amāma'i & Mey & Meyguni \\
$\overline{\text { Āsā }}$ & $\overline{\text { Āsārā'i }}$ & Pers & Persian \\
Diz & Dizini & Shl & Shelnagi \\
Dar & Darbandsari & Shn & Shenestāni \\
Grm & Garmābdari & Shr & Shahrestānaki \\
Hmj & Hamajā'i & Šmš & Shemshaki \\
Irā & Irā'i & Vsk & Veskāra'i \\
Jir & Jirudi & &
\end{tabular}

\section{References}

Borjian, H. (2008): The Extinct Language of Gurgan: Its Sources and Origins. JAOS Vol. 1, No. 4, pp. 681-707.

Borjian, H. (2009): Motun-e Tabari / Tabari Texts. Tehran, Markaz-e pažuheši-e Mirāt-e Maktub.

Borjian, H. (2011): The Extinct Dialect of Tajrish: Caspian or Persian? Journal of Persianate Studies Vol. 4, No. 2, pp. 246-271.

Borjian, H. (2012a): The Dialects of Velattru and Gachsar. The Upper Karaj Valley in the CaspianPersian Transition Zone. JRAS Vol. 22, No. 2, pp. 227-263.

Borjian, H. (2012b): Shemiran Dialect Group. In: Enat'mec'nierebis sakit'xebi/Issues of Linguistics 2011 (Jemshid Giunashvili Festschrift). Tbilisi, Tbilisi State University, pp. 79-90.

Borjian, H. (2013a): Is there Continuity between Persian and Caspian? Linguistic Relationships in the South Central Alborz. New Haven, American Oriental Society.

Borjian, H. (2013b): Yushij: A Dialect of Central Alborz. Persica Vol. 24, pp. 127-153.

Borjian, H. (2013c): The Caspian Dialect of Kujūr in the Central Alborz. Iran. Journal of the Brattish Institute of Iranian Studies Vol. 51, forthcoming.

Deyhim, Giti (2005): Xorda-guyešhā-ye manțaqa-ye Qașrān. Tehran, Farhangestān-e Zabān o Adab-e Fārsi.

Kalbāsi, Irān (2009): Farhang-e towsifi-e gunahā-ye zabāni-e Irān. Tehran, Pažuhešgāh-e 'Olum-e Ensāni.

Kiā, Șādeq (2011): Vāžanāma-ye šașt-o-haft guyeš-e irāni. Tehran, Pažuhešgāh-e 'Olum-e Ensāni.

Lambton, Ann K. S. (1938): Three Persian Dialects. London, Royal Asiatic Society.

Razmārā, Ḥ.-'A. (1950): Farhang-e joghrāfiā'i-e Irān. Vol. III. Tehran, Dāyera-ye Joghrāfiā'i-e Setāde Arteš.

Schmitt, R. (ed.) (1989): Compendium Iranicarum Linguarum. Wiesbaden, Dr. Ludwig Reichert Verlag.

Šokri, Giti (2006): Guyeš-e rāmsari. Tehran, Pažuhešgāh-e 'Olum-e Ensāni. 